\title{
Electrical Power Generation in Aircraft: review, challenges and opportunities
}

\author{
V. Madonna, Student Member, IEEE, P. Giangrande, and M. Galea., Member, IEEE
}

\begin{abstract}
The constant growth of air traffic, the demand for performance optimization and the need for decreasing both operating and maintenance costs have encouraged the aircraft industry to move towards more electric solutions. As a result of this trend, electric power required on board of aircraft has significantly increased through the years, causing major changes in electric power system architectures. Considering this scenario, the paper gives a review about the evolution of electric power generation systems in aircraft. The major achievements are highlighted and the rationale behind some significant developments discussed. After a brief historical overview of the early DC generators (both wind- and engine-driven), the reasons which brought the definitive passage to the $\mathrm{AC}$ generation, for larger aircraft, are presented and explained. Several AC generation systems are investigated with particular attention being focused on the voltage levels and the generator technology. Further, examples of commercial aircraft implementing AC generation systems are provided. Finally, the trends towards modern generation systems are also considered giving prominence to their challenges and feasibility.
\end{abstract}

Index Terms- MEA, AEA, Aircraft Electric Power Generation, HEP, HVDC

\section{NOMENCLATURE}

$\begin{array}{ll}\text { AEA } & \text { All Electric Aircraft } \\ \text { APU } & \text { Auxiliary Power Unit } \\ \text { ATRU } & \text { Autotransformer Rectifier Unit } \\ \text { ATU } & \text { Autotransformer Unit } \\ \text { CF } & \text { Constant Frequency } \\ \text { CSD } & \text { Constant Speed Drive } \\ \text { ECS } & \text { Environmental Control System } \\ \text { GCU } & \text { Generator Control Unit } \\ \text { HP } & \text { High Pressure } \\ \text { HVDC } & \text { High Voltage DC } \\ \text { IM } & \text { Induction Machine } \\ \text { IDG } & \text { Integrated Drive Generator } \\ \text { LP } & \text { Low Pressure } \\ \text { MEA } & \text { More Electric Aircraft } \\ n & \text { Rotational speed of the generator shaft }[\mathrm{rpm}] \\ \text { N1 } & \text { Rotational speed of the low pressure spool }[\mathrm{rpm}] \\ \text { N2 } & \text { Rotational speed of the high pressure spool }[\mathrm{rpm}] \\ p & \text { Number of poles pair of the main generator }\end{array}$

This work is funded by the INNOVATIVE doctoral programme. The INNOVATIVE programme is partially funded by the Marie Curie Initial Training Networks (ITN) action (project number 665468) and partially by the Institute for Aerospace Technology (IAT) at the University of Nottingham.

Vincenzo Madonna ${ }^{1}$, Paolo Giangrande ${ }^{2}$, and Michael $\mathrm{Galea}^{3}$ are all with the Power Electronics, Machines and Control (PEMC) group, University of
PDC Power Distribution Centre

PEC Power Electronics Converter

PM Permanent Magnet

PMSM Permanent Magnet Synchronous Machine

$\mathrm{SiC} \quad$ Silicon Carbide

SR Switched Reluctance

SRM Switched Reluctance Machine

TRU Transformer Rectifier Unit

VFG Variable Frequency Generator

VS Variable Speed

VSCF Variable Speed Constant Frequency

\section{INTRODUCTION}

AECONDARY power systems allow for aircraft safe $\checkmark$ operation and ensure passengers' comfort. For conventional aircraft, secondary power systems combine pneumatic, hydraulic, mechanical and electric power and their energy consumption represents approximately $5 \%$ of the total fuel burnt during the flight [1].

With the advent of the more electric aircraft (MEA) initiative, electric power systems are progressively taking the place of pneumatic, hydraulic and mechanical power systems [2-4]. Over time, this trend has led to an increase of required electric power, particularly for larger aircraft [5-7], as shown in Fig. 1. For instance in the B787, several loads, which were traditionally supplied by pneumatic bleed system, are now electrically-driven [8]. These loads include (but are not limited to) wing ice protection, environmental control system (ECS) and the engine starting system [9]. Therefore, an important player in all of this is the need of on-board electrical power generation. In Fig. 2, a general system-level scheme, regarding the historical evolution of on-board electrical power generation and distribution, is reported $[1,7]$.

The electric power demand on-board of aircraft begun with the requirement of starting the main engines. Hence, power generation on aircraft dates back to the First World War period (1914-18), when the starting capability and also wireless telegraphy were introduced on-board of military aircraft [10]. At the time, wind-driven generators were generally preferred to batteries, mainly due to their better reliability and the poor energy density of the available batteries in the period. Between

Nottingham, Nottingham, NG72RD, UK (' eexvm3@nottingham.ac.uk; ${ }^{2}$ p.giangrande@nottingham.ac.uk; ${ }^{3}$ Michael.Galea@nottingham.ac.uk).

Michael Galea is also with the School of Aerospace, University of Nottingham Ningbo China, Ningbo 315100, China 
the two world wars, electric services, such as lighting, signalling and heating, were brought into use $[3,11,12]$ and with them the power generated by the wind-driven generators escalated from $250 \mathrm{~W}$ up to $1000 \mathrm{~W}$. Higher power ratings were achieved by increasing the generated voltage levels. Indeed, the $6 V d c$ system (already in use in the automotive industry) was soon replaced by the $12 \mathrm{Vdc}$ system, which had been upgraded to the $28 V d c$ system by 1936 [13].

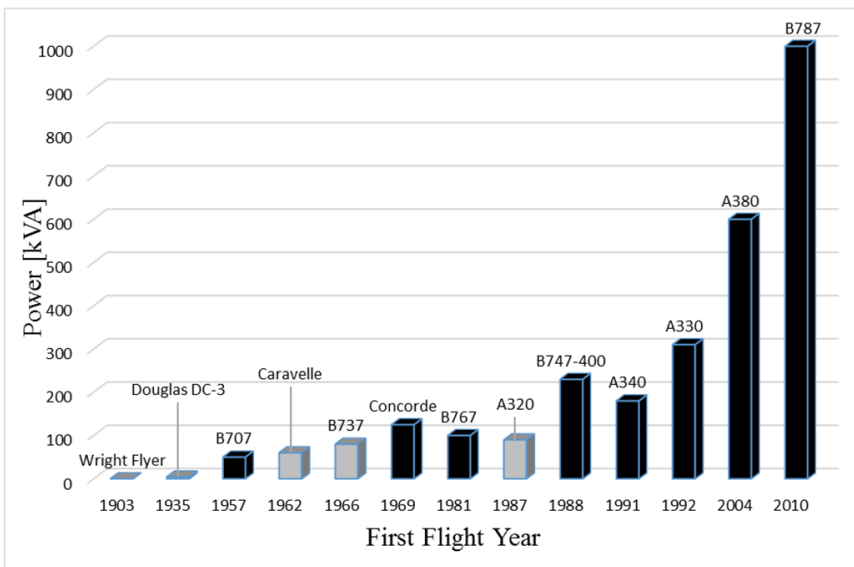

Fig. 1. Evolution of electrical power need (in grey short to medium range aircraft and in black medium to long range aircraft).

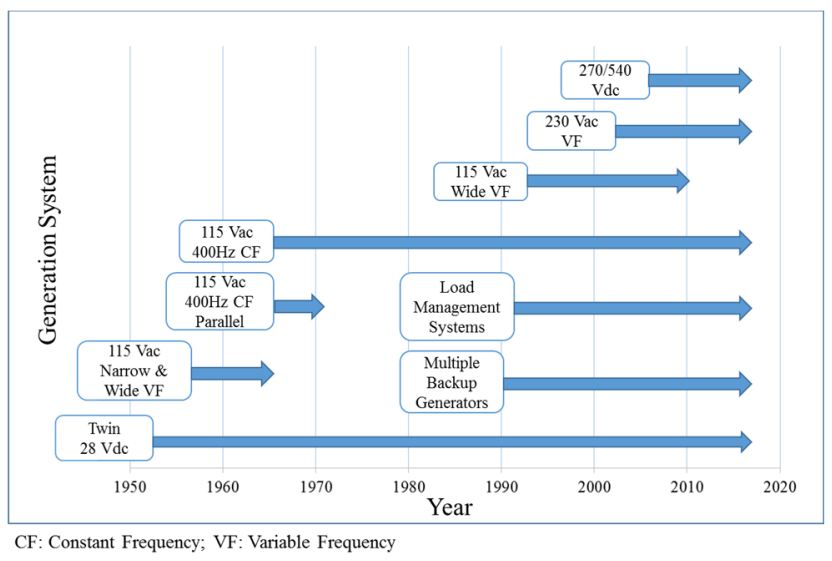

Fig. 2. Electric generation systems evolution.

As the aircraft travelling (ground) speed begun to exceed $280 \mathrm{~km} / \mathrm{h}$ (around 1934), the drag forces related to wind-driven generators started to become a significant issue [14]. For this reason, wind-driven generators were superseded by enginedriven generators. During Second World War (1939-45), engine-driven generators were improved, in terms of power/weight ratio and reliability, however generation was still in DC. In the 1940s and 1950s, twin $28 \mathrm{Vdc}$ engine-driven generators became a standard on-board of many aircraft. Apart from its main two $12 \mathrm{~kW}$ engine-driven generators, it employed one or two batteries (as emergency power source) and a power converter, which fed the AC electric loads [14]. In the 1950s, three-phase generators were mounted on British V-Bombers. These military aircraft used four AC generators providing about $40 \mathrm{kVA}$ each, at $400 \mathrm{~Hz}$ frequency and $115 / 200 \mathrm{Vac}$ voltage [1]. At that time, V-Bombers were one of the first aircraft to implement parallel AC generators [15]. Thirty years later, the
V-Bombers were decommissioned, however, their power generation system is still in service today on the $\mathrm{VC}-10$ air-to-air refuelling tankers. Generating AC voltage at constant frequency required a coupling mechanical gearbox between the variable-speed prime mover (i.e. engine shaft) and the generator [16]. This complex hydromechanical unit introduced reliability issues, due to increased component count (with several moving parts), which needed frequent maintenance [17]. In the early 1990s, the need for more energy-efficient aircraft promoted the MEA concept, which was already known since 1940s. As a result of this trend, commercial aircraft implementing moreelectric features are nowadays available and some examples are the A380 and the B787 [3].

Starting from the dawn of aviation, this paper presents a survey on the evolution of electrical power generators for aerospace applications. In particular, DC power generation is discussed in Section II, where the technologies implemented pre- and post- World Wars are examined. In Section III, the AC power generation technologies, such as constant frequency (CF) and variable speed constant frequency (VSCF) systems, are described and their main advantages and drawbacks are highlighted. Section IV deals with "unconventional systems", such as switched reluctance machine (SRM) based systems, for generating electric power on-board of military aircraft. Recent achievements and today's generation systems employed in MEA are considered in Section V. The challenges and forthcoming developments regarding the power generation on the future aircraft (i.e. multi-spool generation and HVDC systems) are briefly reviewed in Section VI. Finally, Section VII provides a summary through more than a hundred years of electric power generation on-board of aircraft.

\section{II.DC GENERATION}

In the early days, electric power on aircraft was mainly used for communication and ignition systems. Indeed, the first DC generators were typically rated for less than $500 \mathrm{~W}$ and usually adopted $6 V d c$ and $12 V d c$ voltage levels $[11,12]$. As previously mentioned, the installation of lighting, signalling and heating systems increased the electric power requirements. Hence, the generator capacity rose up to $1 \mathrm{~kW}$ (value retained till the beginning of World War II [18]), as well as the voltage level, which was increased to $28 \mathrm{Vdc}$. Higher generated voltage allowed for savings on cables and commutators weight $[13,19$, 20].

\section{A. Pre-World War II}

The majority of the first DC generators relied on wind-driven technologies [19]. This topology of generator was most commonly mounted externally on the aircraft's landing gear strut. However, as aircraft speeds increased, requirements for more refined flight dynamics started to push towards fully retractable landing gear and thus wind-milling generators became obsolete. The era of engine-driven generators thus began [21]. Table I combines the two 'families', i.e. wind-driven and engine-driven generators, and reports the main characteristics of some of these early DC aircraft generators $[11,12,19,21]$. Engine-driven DC generators were designed for speeds between $3200 \mathrm{rpm}$ and 6000rpm, according to the 
prime mover speed, and allowed for short time overloads [19]. The overload capability was usually aimed at $50 \%$ of the rated power. In order to ensure light weight, the generator housing and its accessories, such as supporting brackets, were typically made of magnesium alloys [20,22]. Indeed, these alloys were preferred to aluminium alloys, because their mass density is about two thirds of the aluminium ones.

TABLE I - EARLY DC GENERATORS FOR AIRCRAFT

\begin{tabular}{|c|c|c|c|c|c|}
\hline $\begin{array}{c}\text { DC } \\
\text { Generator }\end{array}$ & $\begin{array}{c}\text { Electrical } \\
\text { parameters }\end{array}$ & $\begin{array}{l}\text { Speed } \\
{[k r p m]}\end{array}$ & $\begin{array}{c}\text { Weight } \\
{[\mathrm{kg}]}\end{array}$ & $\begin{array}{c}\text { Approx. } \\
\text { date }\end{array}$ & $\begin{array}{c}\text { Power } \\
\text { density } \\
{[\mathrm{kW} / \mathrm{kg}]}\end{array}$ \\
\hline \multirow{3}{*}{$\begin{array}{l}\text { Wind } \\
\text { Driven }\end{array}$} & $12 \mathrm{~V}, 250 \mathrm{~W}$ & 3.5 & 5.5 & 1924 & 0.05 \\
\hline & $12 \mathrm{~V}, 500 \mathrm{~W}$ & 4.5 & 6.4 & 1924 & 0.08 \\
\hline & $12 \mathrm{~V}, 1 \mathrm{~kW}$ & 3.5 & 12.3 & NA & 0.08 \\
\hline \multirow{7}{*}{$\begin{array}{l}\text { Engine } \\
\text { Driven }\end{array}$} & $12 \mathrm{~V}, 500 \mathrm{~W}$ & 3.8 to 6 & 9.8 & 1934 & 0.05 \\
\hline & $28 \mathrm{~V}, 1 \mathrm{~kW}$ & 3.8 to 6 & 16.3 & 1936 & 0.06 \\
\hline & $28 \mathrm{~V}, 1.5 \mathrm{~kW}$ & 3.3 to 6 & 15.4 & 1941 & 0.10 \\
\hline & $28 \mathrm{~V}, 3 \mathrm{~kW}$ & 3 to 6 & 27.2 & 1943 & 0.11 \\
\hline & $28 \mathrm{~V}, 6 \mathrm{~kW}$ & $\begin{array}{c}3.25 \text { to } \\
4.8\end{array}$ & 25.4 & 1944 & 0.24 \\
\hline & $\begin{array}{c}28 \mathrm{~V}, \\
11.2 \mathrm{~kW}\end{array}$ & 6 & NA & 1953 & NA \\
\hline & $\begin{array}{c}112 \mathrm{~V}, \\
22.5 \mathrm{~kW}\end{array}$ & $2.9-10$ & 63 & 1956 & 0.36 \\
\hline
\end{tabular}

Fig. 3 shows an example of an early engine-driven DC generator rated $1 \mathrm{~kW}$ at $28 \mathrm{Vdc}$. In terms of the cooling system, DC generators were usually air-cooled through a fan (installed on an engine shaft extension), whose material might vary according to the mechanical damping required by the engine [20]. Magnesium or aluminium were usually employed, however, heavier metals were used if an additional flywheel effect was needed by the engine. The main components of a typical DC aircraft generator are reported in Fig. 4, where the generator exploded view is depicted [20, 23].

\section{B. Post-World War II}

After World War II, the trend in aircraft power generation was to move towards AC generation systems. Nevertheless, DC generators still continued to be developed and used, mainly based on the knowledge and expertise gained by their adoption in the previous years. In the early 1950s, a customized DC starter-generator was built for the Republic F-84 Thunderjet.

This starter-generator was able to continuously operate at $7500 \mathrm{rpm}$, while providing a current of $400 \mathrm{~A}$ [24]. In order to reduce the cabling weight, $\mathrm{DC}$ generators operating at $120 \mathrm{Vdc}$ were also introduced on some aircraft [13], since higher voltage implies lower current for a given power. However, higher voltage systems always presented (and still do) significant concerns related to safety and risk, especially for DC systems dependant on electro-mechanical commutation. Indeed, based on Paschen's law, the breakdown voltage between two electrodes, at a fixed distance in air, decreases with increasing altitude (i.e. decreasing pressure) [25].

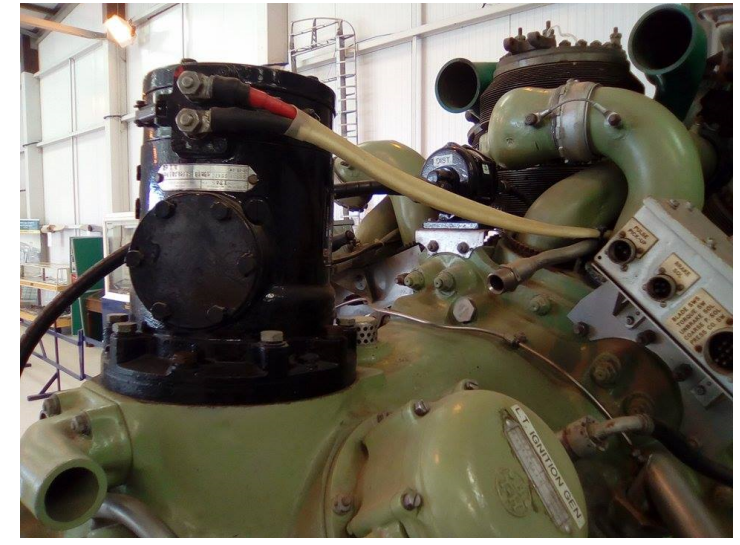

Fig. 3. $1 \mathrm{~kW}$ at $28 \mathrm{Vdc}$ engine-driven DC generator, stored in the Shuttleworth Museum (Biggleswade, UK).

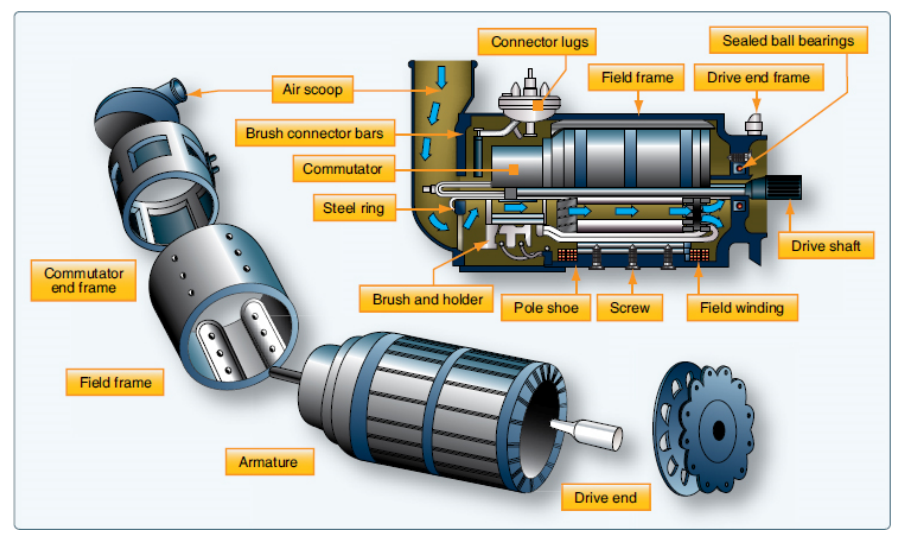

Fig. 4. Exploded view of a typical $28 \mathrm{Vdc}$ aircraft generator [23].

As a consequence, at high altitude, a lower voltage (with respect to ground level) is necessary to sustain electric arcing, which is the cause of premature brushes/commutator wear out and reliability issues. For most small and medium-sized aircraft, generation at $28 \mathrm{Vdc}$ still represents a feasible operating system [13]. However, low voltage DC systems, which have been so successful in the past, are no longer sufficient for the higher amount of electric power demanded today [26], especially in the case of larger aircraft. For example, the modern Airbus A380-800 (which operates at 115 Vac) counts a total wire length of about $470 \mathrm{~km}$, with a total weight of $5700 \mathrm{~kg}$ [27]. This weight would be more than tripled, if the aircraft electrical distribution system voltage was $28 \mathrm{Vdc}$ [28]. Nowadays, many small modern aircraft make use of DC generators for both main and backup generation systems. Some examples of civil aircraft employing 28Vdc starter-generators are 1) ATR-600, 2) Dornier 328, 3) Gulfstream G280 and 4) Falcon 2000. A number of military aircraft using $28 \mathrm{Vdc}$ starter-generators include 1) the Alpha jet, 2) the C295, 3) the CN235 and 4) the IJT-36 [29]. In Table II, the main features of the modern DC generators are listed.

Comparing Table I and II results, the higher power density (ratio power/mass) of modern DC generators is immediately observable. In fact, its value has more than doubled. 
TABLE II - CHARACTERISTICS OF MODERN ENGINE DRIVEN DC GENERATORS FOR AIRCRAFT (COURTESY OF THALES GROUP) [29]

\begin{tabular}{|c|c|c|c|c|}
\hline $\begin{array}{c}\text { Electrical } \\
\text { parameters }\end{array}$ & $\begin{array}{c}\text { Speed } \\
{[\mathbf{k} \boldsymbol{r} \boldsymbol{p m}]}\end{array}$ & $\begin{array}{c}\text { Weight } \\
{[\mathbf{k g}]}\end{array}$ & $\begin{array}{c}\text { Approx } \\
\text { Date }\end{array}$ & $\begin{array}{c}\text { Power } \\
\text { Density } \\
{[\boldsymbol{k} \boldsymbol{W} / \mathbf{k g}]}\end{array}$ \\
\hline $28 \mathrm{~V}, 4.8 \mathrm{~kW}$ & $8-12.15$ & $7.8-8$ & 2014 & $0.6-0.62$ \\
\hline $28 \mathrm{~V}, 6 \mathrm{~kW}$ & $7-12.15$ & $9-11$ & 2014 & $0.54-0.67$ \\
\hline $28 \mathrm{~V}, 9 \mathrm{~kW}$ & $4.5-12.3$ & $16-21$ & 2014 & $0.43-0.56$ \\
\hline $28 \mathrm{~V}, 12 \mathrm{~kW}$ & $7-12.8$ & $17-19$ & 2014 & $0.63-0.71$ \\
\hline
\end{tabular}

\section{AC GENERATION}

As mentioned above, most aircraft were still DC powered even after World War II. However, from the "60s onwards, increasing speeds and aircraft size led to an unprecedented increase of required electric power. Furthermore, specifications, such as reliability and power density, became ever more critical. For these reasons, a general world-wide move towards $\mathrm{AC}$ generation was observed [13, 30], which reveals several advantages compared to DC generation. First of all, a significant improvement is achieved in terms of power density (i.e. $\mathrm{AC}$ generators are lighter and smaller in comparison to equal rated power DC generators). In 1950s generators, the power density for the DC topology was generally below $0.5 \mathrm{~kW} / \mathrm{kg}[13,22]$. Their AC counterparts ranged from $0.66 \mathrm{kVA} / \mathrm{kg}$ to $1.33 \mathrm{kVA} / \mathrm{kg}[13,18,22]$, thus highlighting the significant benefits of producing electric power in AC. A relevant advantage is the potentially much higher operating voltage. In particular, a considerable cabling weight reduction was accomplished by increasing the operating voltage (i.e. decreasing the current for the same power) [13]. From a reliability perspective, the absence of commutators on $\mathrm{AC}$ generators improved maintenance and lifetime performance [22], despite the higher voltage and power levels.

However, the advent of AC generators also introduced new challenges, mainly due to 1) the parallel operations, 2) the need to manage reactive power and 3) the choice of an appropriate frequency. Indeed, AC generators can be operated in parallel, when the developed voltages have the same amplitude, phase and frequency. Conversely, only the same voltage amplitude is needed for DC generators. Furthermore, unlike AC systems, the DC ones do not involve reactive power, hence the related issues (e.g. power factor correction) are avoided.

Several frequency values $(60 \mathrm{~Hz}, 180 \mathrm{~Hz}, 240 \mathrm{~Hz}, 360 \mathrm{~Hz}$, $400 \mathrm{~Hz}$ and $800 \mathrm{~Hz}$ ) were initially considered [13]. A frequency of $240 \mathrm{~Hz}$ was suggested at the beginning of $1940 \mathrm{~s}$, for keeping motors and transformer weight to a practical minimum [30]. Obviously, this choice was also dictated by the magnetic materials available at that time. Nevertheless, the frequency selection must take into account also the generator operating speed [22]. Considering this aspect, suitable frequency values were $400 \mathrm{~Hz}$ and $800 \mathrm{~Hz}$. Based on respective needs and requirements, the Army Air Corps in 1943 chose $400 \mathrm{~Hz}$ as the standard frequency, since it appeared to be more feasible for the generator speed (e.g. 12000 rpm for 4-pole machines) [30, 31]. This 'standard' of $115 / 200 \mathrm{~V}$ at $400 \mathrm{~Hz}$ frequency has been made mandatory for use by the US Air Force in 1959 (MIL-STD-704) and has remained with us to this day.

The voltage level of $115 / 200 \mathrm{~V}$ was deemed high enough to transmit high power over a convenient distance, while still low enough to avoid the devastating phenomena associated to corona effects at altitude $[11,12,19,21]$. An important step towards the AC generation was made in 1949 with the entry into service of the Convair B 36, which was equipped with four $30 \mathrm{kVA}$ synchronous generator (one per engine) [21, 32]. In the next sub-paragraphs, the most common $\mathrm{AC}$ electric power systems are discussed and analysed.

\section{A. AC Constant Frequency Systems}

The three-stage wound-field synchronous generator is the most popular AC generator used on aircraft [33, 34]. This popularity is due to its inherent safety, since the excitation can be instantaneously removed by de-energising the machine through direct control of the field [35, 36]. In Fig. 5, a schematic diagram of a three-stage wound-field synchronous generator is depicted, where the three principal stages, namely 1) the PM generator, 2) the main exciter and 3) the main generator, are shown [37]. The generation system is powered by the PM generator ( $1^{\text {st }}$ stage), whose moving PMs induce a three-phase voltage in its stationary armature. This AC voltage is then rectified and used for suppling stationary field circuit (i.e. DC field) of the main exciter ( $2^{\text {nd }}$ stage), by means of the generator control unit (GCU). The GCU fulfils two essential tasks on the DC field: 1) controls the DC voltage amplitude, for regulating the excitation current of the main generator ( $3^{\text {rd }}$ stage), and 2) de-energises the DC circuit in case of anomalous operations (e.g. excessive overload, short circuit faults etc...) $[5,38]$. The DC field induces a three-phase voltage in the moving armature of main exciter. Such AC voltage is subsequently converted into DC, for feeding the moving field circuit of the main generator. The $\mathrm{AC}$ to $\mathrm{DC}$ conversion is performed by a rectifier, which is rotating synchronously with the prime mover shaft. Finally, the three-phase voltage is available at the output of the main generator armature. Its frequency depends on: 1 ) the main generator number of poles pair $(p)$ and 2) the mechanical rotational speed of the prime mover shaft $(n)$. Thus, the frequency is closely reliant on the speed of the prime mover.

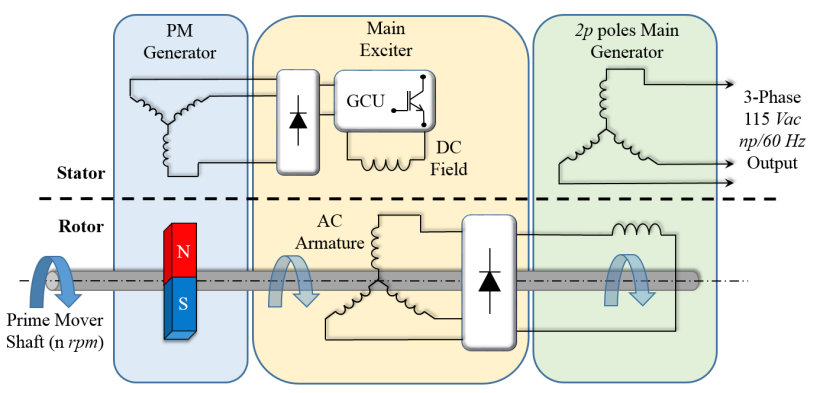

Fig. 5. Architecture of the three-stage wound-field synchronous generator.

For on-board power generation, the prime mover is usually the main aircraft engine, whose speed varies across a wide range, from idle to full power. Hence, the prime mover variable speed represented the main challenge in the adoption of the three-stage wound-field synchronous generator and actions were required for addressing this issue. Therefore, the engine 
and the three-stage generator shaft were mechanically coupled through a variable-ratio transmission gearbox referred as constant speed drive (CSD) [39], like schematically illustrated in Fig. 6. The CSD converts the input variable speed to the output constant speed, which is used to drive the AC generator. By using CSDs, the challenge of variable speed was eliminated, at the cost of a bulky, expensive and component count enhancing, extra gearbox. Constant frequency generation systems adopting CSDs and producing $115 / 200 \mathrm{~V}$ at $400 \mathrm{~Hz}$ have been widely used in aircraft since the 1960s [40].

The 1970s saw a move towards integrating the generator stages and the CSD into a single unit, in order to achieve weight reduction, as well as enhanced reliability $[40,41]$. In that period, CSDs had far longer mean time between failures with respect to generators [40]. Consequently, the integration into a common housing improved the overall system-level reliability [39]. Considerable reduction in weight and size was obtained by designing a common oil system for both generator cooling and CSD lubrication [42]. This compact unit was named integrated drive generator (IDG) and allowed a power density improvement from $0.88 \mathrm{kVA} / \mathrm{kg}$ (typical value for CSD + generator systems) to about $1.5 \mathrm{kVA} / \mathrm{kg}[35,43,44]$. IDG systems were very popular for over 20 years, due to their efficiency and power density values. Indeed, a number of aircraft, such as the A320, A330, A340, B747, B757, B767 and B777, implemented IDG systems [6, 14]. The block diagram of an IDG system is shown in Fig. 6 [16], while, civil and military aircraft employing traditional AC constant frequency systems are listed in Table III [3, 45-48]. IDGs usually have a short-time overload capability of approximately $185 \%$ of the rated power [49]. For example, the $120 \mathrm{kVA}$ IDG of the B777 can safely deliver up to $226.8 \mathrm{kVA}$ for 5 minutes, every 1000 hours of operation [49].

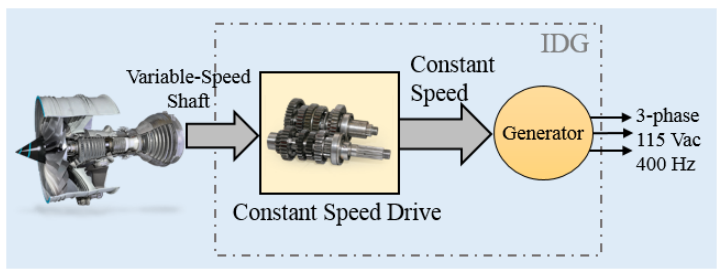

Fig. 6. Constant frequency IDG system.

On civil aircraft, dual spool turbofan engines are commonly installed. According to the operating pressure, these engines are characterised by two main sections: 1) the low pressure (LP) sector, which includes the fan, the LP compressor and the LP turbine, and 2) the high pressure (HP) sector, which comprises the HP compressor and the HP turbine [50]. In dual spool turbofan engines, the IDG is driven by the HP spool (i.e. HP shaft) through a fixed ratio accessory gearbox, as schematically reported in Fig. 7 [34, 50, 51]. Considering the GE90 engine mounted on the B777, the rotational speed of the HP spool is equal to $9333 \mathrm{rpm}$, while the IDG is driven by a gear-to-core ratio of 0.79:1 [49]. For sake of clarity, the speed of 9333rpm $(100 \%)$ represents the "normal" operating speed, which in some cases (e.g. during take-off) can be exceeded by some \% [52].
TABLE III - POWER RATING FOR AC CONSTANT FREQUENCY SYSTEMS

\begin{tabular}{|c|c|c|c|}
\hline Aircraft Model & $\begin{array}{c}\text { First year } \\
\text { of service }\end{array}$ & $\begin{array}{c}\text { (Approx.) } \\
\text { Passenger } \\
\text { capacity }\end{array}$ & $\begin{array}{c}\text { Main Generators } \\
\text { Power (Excluding } \\
\text { APU) }\end{array}$ \\
\hline Convair B-36 & 1949 & (Military) & $4 \times 30 \mathrm{kVA}$ \\
\hline Boeing B-52H & 1955 & (Military) & $4 \times 60 \mathrm{kVA}$ \\
\hline Boeing 707 & 1958 & 219 & $4 \times 30 \mathrm{kVA}$ \\
\hline Boeing 727 & 1964 & 189 & $3 \times 38 \mathrm{kVA}$ \\
\hline Vickers VC10 & 1964 & 151 & $4 \times 40 \mathrm{kVA}$ \\
\hline Boeing 737 (NG) & $1968(' 97)$ & 210 & $2 \times 90 \mathrm{kVA}$ \\
\hline Airbus A320 & 1987 & 220 & $2 \times 90 \mathrm{kVA}$ \\
\hline Boeing 747-800 & 1988 & 660 & $4 \times 90 \mathrm{kVA}$ \\
\hline Boeing 767-300ER & 1988 & 258 & $2 \times 90 \mathrm{kVA}$ \\
\hline Airbus A340 & 1991 & 375 & $4 \times 90 \mathrm{kVA}$ \\
\hline Airbus A330 & 1992 & 335 & $2 \times 115 \mathrm{kVA}$ \\
\hline Boeing 777 & 1994 & 396 & $2 \times 120 \mathrm{kVA}$ \\
\hline Boeing 717 & 1999 & 100 & $2 \times 40 \mathrm{kVA}$ \\
\hline Boeing 767-400ER & 2000 & 256 & $2 \times 120 \mathrm{kVA}$ \\
\hline
\end{tabular}

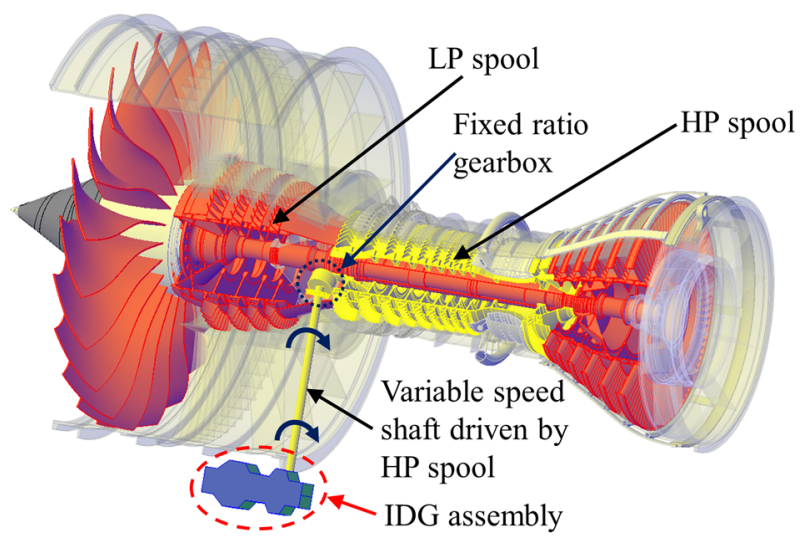

Fig. 7. Typical dual spool turbofan engine $[50,53]$.

\section{B. AC Variable Speed Constant Frequency Systems}

The CSD adopted for AC constant frequency systems required maintenance and contributed in a significant way to both weight and size of the system. For these reasons, new approaches for generating $\mathrm{AC}$ power at constant frequency were introduced in the 1980s [54] and they took hold in the 1990s. Indeed in the 1900s, power electronics and microprocessor technologies were by then mature enough to allow the significant progress in electrical drives to be employed also in aerospace [43, 55-57]. The VSCF system works without the heavy CSD, whereby the three-stage synchronous generator can be directly coupled to the main engine shaft. In this case, the frequency of the generated voltage is variable, so in order to provide constant frequency voltage, two approaches are adopted. The first method consists in implementing a $\mathrm{DC}$ link between the $\mathrm{AC}$ generator and the $\mathrm{AC}$ loads, by means of a rectifier and an inverter $[40,55]$. The block diagram of the VSCF system with DC link is shown in Fig. 8 [38]. The VSCF system using a DC link was mounted on the MD-90 until 2000 and it is still in used on the B777, for the two $20 \mathrm{kVA}$ backup generators [43]. These backup power sources generators are driven by the engine HP spool through a 2.41:1 fixed-ratio accessory gearbox [49]. 


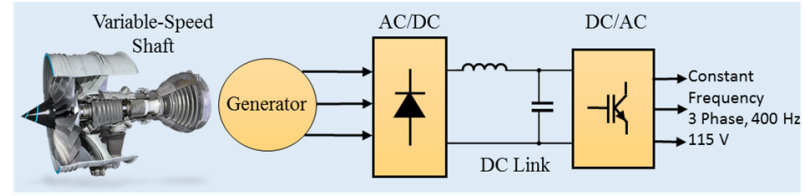

Fig. 8. VSCF system using DC link.

Another method for generating constant frequency voltage involves an $\mathrm{AC} / \mathrm{AC}$ converter (e.g. cycloconverter or matrix converter), which is placed between the $\mathrm{AC}$ generator and the AC loads. Fig. 9 reports the block diagram of the VSCF system with AC/AC converter [39]. This architecture is mainly implemented on military aircraft, such as for the F-18 fighter aircraft, the F-117A stealth attack aircraft and the V-22 ultrahigh altitude reconnaissance aircraft $[14,58]$.

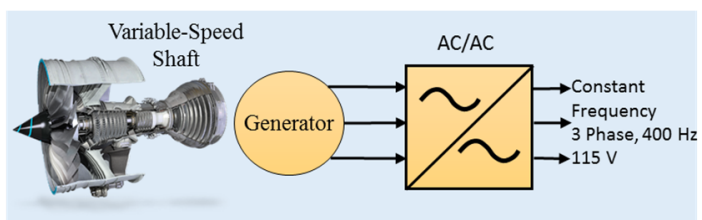

Fig. 9. VSCF system using AC/AC converter.

The VSCF systems, apart for some noteworthy exception previously mentioned, did not get the same level of diffusion of IDG systems. This can be safely attributed to the role played by the power electronics converter (PEC) (either AC/DC or $\mathrm{AC} / \mathrm{AC}$ ), which processes all the generated power and represents a single point of failure. Therefore, the PEC needs to be designed for the full power rating and with high reliability requirements [38]. In addition, several aircraft energyconsuming loads (e.g. wing ice protection, galley ovens, cargo heaters) are frequency insensitive (i.e. resistive loads) [9]. Thus, they can be directly supplied by the variable frequency generator (VFG), without the need of PECs. This feature led to the variable frequency systems that are discussed in Section V.

\section{Concluding remark}

In general, VSCF systems are more flexible than constantspeed constant-frequency systems (i.e. IDG systems), due to the inherent distribution of components throughout the aircraft [55]. Indeed, the IDG systems make use of the CSD, which must be placed close to the main engine, while the PECs of the VSCF system can be either installed close to the engine or in a different location (e.g. close to the electric loads), allowing aircraft weight distribution optimisation. Despite their advantages, the VSCF systems remain a rare choice for civil aircraft, due to the reliability level of PECs. In fact, the PECs have not yet reached a proper reliability level for making the VSCF systems a viable option [38].

\section{UNCONVENTIONAL SYSTEMS}

In terms of DC generation, the majority of aircraft employ $28 \mathrm{Vdc}$ or $120 \mathrm{Vdc}$ generators, while the three-stage synchronous-generator producing $115 / 200 \mathrm{~V}$ at $400 \mathrm{~Hz}$ is the common solution in case of AC generation. However, some exceptions to these widespread solutions can be found in military applications. These particular generation systems are also known as "unconventional systems" and the more important are considered in this section.

SRMs have been in use since the nineteenth century [59], but their need for custom-built power electronics and control algorithms prevented a more extensive implementation. Regarding the SRM structure, its stator is equipped with concentrated windings wound around the stator poles, while the rotor is a totally passive salient-pole geometry (i.e. solid or laminated electrical steel without any permanent magnets (PMs) or field windings). The SRM working principle is based on the natural tendency of any system to come to rest at the 'minimum-energy' position. The stator poles (when excited) attract the nearest rotor poles (i.e. position of minimum reluctance for the magnetic flux) [60]. In order to operate the SRM as a generator, the phase must be excited as the rotor poles move through the aligned position [60]. Precise rotor position monitoring, as well as, accurate control algorithms are necessary for optimal power generation.

Due to developments of both power electronics and design procedures, SRMs have become suitable candidates for integrated starter-generators [61-66]. The success of the SRM relies on its inherent fault tolerance capability and rotor robustness [67-71]. Indeed, adopting a multiphase design, together with the power segmentation approach (i.e. each machine phase is supplied by an independent PEC), allows to safely operate the machine even under electromagnetic and/or PEC faults [72]. The absence of PMs reduces the risks associated with machine winding faults [71] and favours operations in harsh environments, where PMs could be subject to demagnetisation or performance derating. Finally, the salient-pole one-material rotor is easy to manufacture and makes the SRM convenient for high speed applications [70]. These features have contributed to the SRMs employment, mainly on military aircraft. In 2005, the Lockheed Martin F-22 came into service. This is a modern two engine combat aircraft, using as many switched reluctance (SR) generators. Although the electric power is generated at $270 \mathrm{Vdc}$, the F-22 is fitted with electric loads requiring $115 \mathrm{Vac}$ and $28 \mathrm{Vdc}$, which are supplied through PECs [14]. Fig. 10 shows the F-22 power generation and distribution systems [14]. A similar architecture has been also implemented on the Lockheed Martin F-35 (i.e. single engine combat aircraft), that was launched in 2015. For redundancy purposes, an $80 \mathrm{~kW}$ double channel SR generator is adopted [73, 74].

Considering voltage level, reliability, efficiency and faulttolerance capability, traditional brushed DC machines cannot reach the same performance of SRMs. Thus, SRMs are suitable for generating DC power at high voltage, avoiding the electric arcing issue typical of the brushes/commutator system. SRMs are characterized by indisputable advantages (i.e. rotor robustness and inherent fault tolerance capability), notwithstanding their drawbacks (i.e. uncustomary PECs and complex control algorithms) restrict a wider adoption. In fact, while very popular for military aircraft due to the lower power generation requirements, as the demanded power increases (i.e. 
in civil aircraft), $\mathrm{AC}$ generation is then generally preferred, for the reasons discussed in Section III.

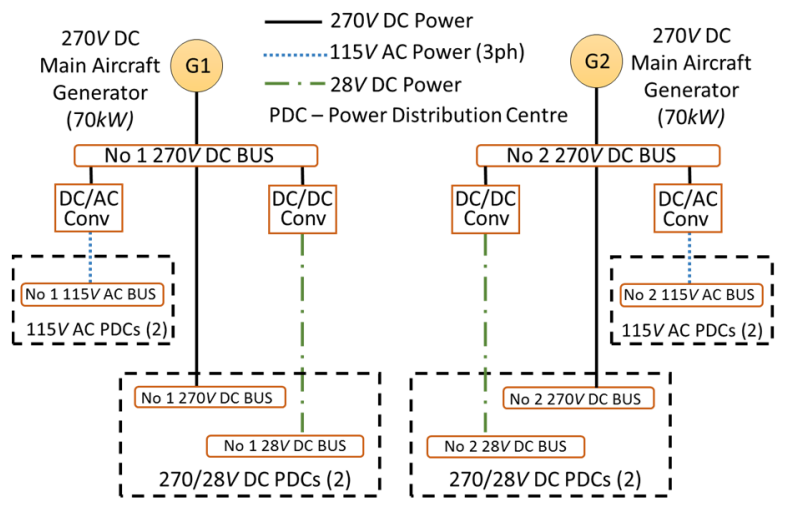

Fig. 10. F-22 power generation and distribution system [58].

\section{V.THE MORE ELECTRIC AIRCRAFT ERA}

The above is all related to existing and consolidated systems for on-board electrical power generation. However, as previously mentioned, a considerable shift towards more electric systems is in play today. The MEA concept revolves around the idea of replacing most of the aircraft secondary systems, currently operated by mechanical, hydraulic and pneumatic power, with systems powered by electricity $[38,75]$. Some early examples of the MEA concept go back to the mid1950s with the Vickers Valiant V-Bomber and the Bristol Brabazon 167 [1]. Albeit the feasibility and availability of the MEA concept is debatable and is still in question today, a revamped interest in the MEA initiative started in the early 1990s, when the US Air Force began several research programs concerning MEA. In particular, these programs focused on improving reliability, fault tolerant capability and power quality of existing MEA systems, with the final purpose of reducing both fuel burn and weight of aircraft secondary power systems [2]. An immediate consequence of the MEA concept is the significant increase (in the absolute numbers) of the required electric power. For this reason, today, electrical power generation is a major game-changing factor across the whole industry.

\section{A. Modern MEA programmes}

A number of aircraft have been claimed to incorporate MEA designs, nevertheless it is widely acknowledged that the two programmes, which have really and seamlessly integrated the MEA concepts, are the long-haul, wide bodied commercial aircraft known as the Boeing 787 and the Airbus A380 [38].
These aircraft are characterized by an intensive electrification, since services like the ECS (for B787) and flight-control electro hydrostatic actuators (for A380) are electrically powered. Consequently, their electric generation capability is roughly of an order of magnitude greater than all other aircraft. Both the B787 and A380 have replaced the traditional generation system employing IDGs, by VFGs directly coupled to the engines. The B787 main electrical power generation relies on four $250 \mathrm{kVA}$ VFGs (two per each main engine), while the A380 uses four $150 \mathrm{kVA}$ VFGs (one per engine), as reported in Table IV [3].

The implementation of the so-called bleed-less architecture permits to electrically supply services (e.g. ECS and wing ice protection), which were pneumatically operated on conventional aircraft. In bleed-less technology, no HP air is extracted from the engines (i.e. no-bleed air), allowing more efficient thrust production and engine operations $[7,8,76]$. Indeed, in most conditions, conventional pneumatic systems withdraw more power than needed, causing excess energy to be dumped overboard [8].

TABLE IV - POWER GENERATION CAPABILITIES FOR SOME MODERN AIRCRAFT

\begin{tabular}{|c|c|c|}
\cline { 2 - 3 } \multicolumn{1}{c|}{} & Boeing 787 & Airbus A380 \\
\hline No. of engine & 2 & 4 \\
\hline No. generator per engine & 2 & 1 \\
\hline Generator rating & $250 \mathrm{kVA}$ & $150 \mathrm{kVA}$ \\
\hline Generating output voltage & $230 \mathrm{VAC}$ & $115 \mathrm{VAC}$ \\
\hline No. generator per APU & 2 & 1 \\
\hline Generator rating per APU & $225 \mathrm{kVA}$ & $120 \mathrm{kVA}$ \\
\hline
\end{tabular}

The bleed-less architecture of the B787 reduces the fuel consumption by $2 \%$ (at cruise condition) with respect to a similar-sized traditional aircraft (e.g. B767) [8]. Nonetheless, removing the pneumatic system increases the complexity of the electric power distribution network [9]. This aspect is highlighted in Fig. 11, where the B787's distribution system is schematically compared with that of a traditional aircraft, together with some examples of electrically-operated loads [9, 43]. As earlier mentioned, several energy-consuming loads are frequency-insensitive. Therefore, they are directly supplied by the VFGs, without the need of PECs (see Fig. 11, B787 diagram). The other loads (operating at $115 \mathrm{Vac}, 270 \mathrm{Vdc}$ or $28 \mathrm{Vdc}$ ), are connected to the VFGs through transformers and/or PECs, implementing the so-called hybrid distribution system.

The transition to a more electric architecture, the adoption of energy efficient engines and the intensive use of lightweight composite materials have contributed to a considerable reduction of the B787's operating cost with respect to its predecessor the B767-300/ER [77, 78]. In particular (based on airlines' data), the block hour operating cost reduction is about $14 \%$ [78-80]. 


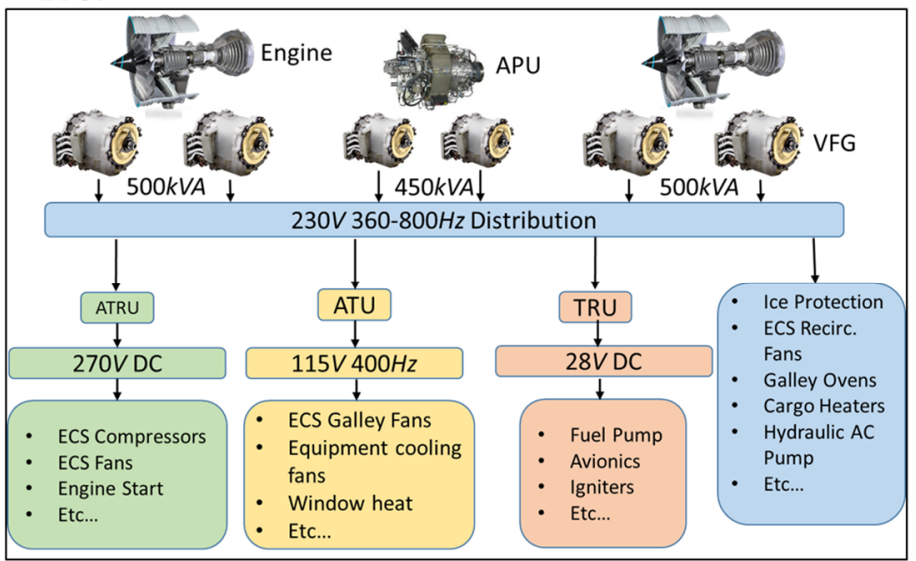

Traditional (e.g. B767, B777)

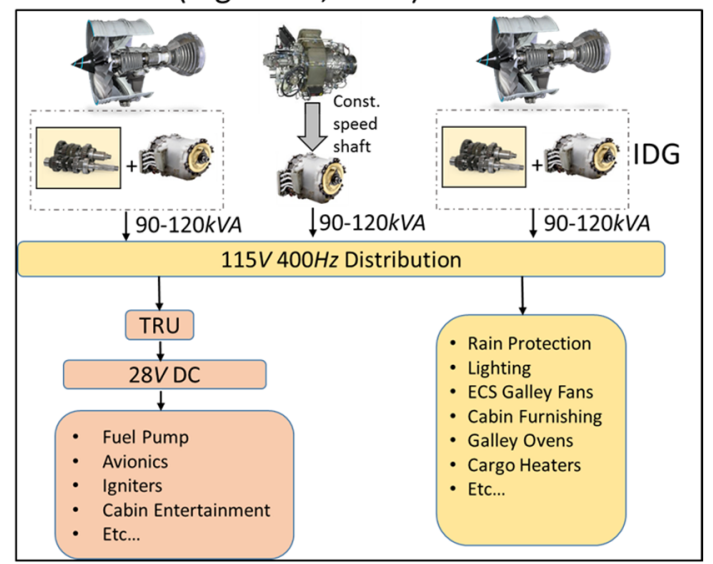

ATRU: Autotransformer Rectifier Unit; ATU: Autotransformer Unit; TRU: Transformer Rectifier Unit

Fig. 11. Simplified diagrams of electric distribution systems for both B787 and traditional aircraft.

\section{B. Modern developments at component level}

Currently, three-stage wound-rotor generators are used as VFGs. However, PM generators can and are being considered as alternative, thanks to their higher power density (from $3.3 \mathrm{kVA} / \mathrm{kg}$ to $8 \mathrm{kVA} / \mathrm{kg}$ ) [61-63]. Variable frequency generation systems do not require the CSD between $\mathrm{AC}$ generator and main engine, since they are directly coupled (i.e. direct-drive application), as sketched in Fig. 12.

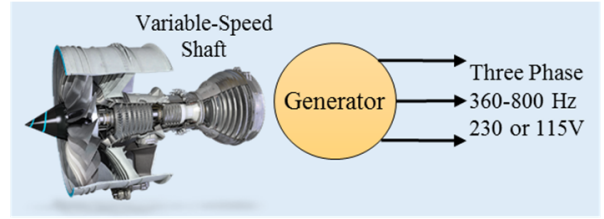

Fig. 12. VFG systems.

The absence of a gearbox improves the system-level reliability, due to the reduced component count, whilst other advantages are associated to the weight and size of the system [47]. As a consequence of the shaft variable speed, the VFG output voltage is variable in amplitude and frequency. Considering the case of a three-stage wound-rotor generator used as VFG, the output voltage amplitude is regulated by acting on the field current through the GCU, as mentioned in Section III. Conversely, reactive power is injected into the armature circuit (by using a PEC), when a PM generator is employed as VFG [81]. According to the aircraft mission profile, the output frequency varies from $360 \mathrm{~Hz}$ to $800 \mathrm{~Hz}$ during take-off and landing, while it is almost unchanged for the rest of the flight (about $80 \%-90 \%$ of the total flight duration). Challenges related to the VFGs adoption are the cooling system and the mechanical design. In effect, the proximity to the main engine imposes a careful thermal management. Besides, the direct-drive application subjects the rotor to high accelerations, which must be accounted during the mechanical design [82].

\section{Overall power generation}

An overall view of how the MEA initiative is influencing the required ratings of on-board electrical generators is summarized in Fig. 13. For the years from 1940s to 2010s, Fig. 13 shows the trend of the generated power on some of the more common aircraft, where the absolute power (in terms of total electrical power generation) is translated to the rating requirements of the single component [45-48]. As highlighted in Fig.13, the global rated power has significantly increased, in the last ten years. It is perceived that this tendency is mainly caused by the move towards the MEA concept. Indeed, for the 20 years prior to the MEA era (from 1970s and 1990s), the main generator rated power remained unchanged and equal to about $90 \mathrm{kVA}[1,52]$.

\section{FUTURE TRENDS BEYOND THE MEA}

While the aerospace community is still debating the feasibility and implementation of the MEA, a new movement, that has taken hold over the last couple of years and is creating a lot of excitement, is represented by both the hybrid gas/electric propulsion and the all-electric aircraft (AEA). Although in recent years the price of Jet-A fuel has considerably dropped, forecasts suggest a turnaround during the next decade [83]. At the same time, year-over-year, the passenger-travel growth has averaged $6.2 \%$, from 2012 to 2017 , and it is expected an even higher growth rate in the next 20 years [83, 84]. The two aforementioned factors, together with the airlines' need for reducing aircraft operating cost, are encouraging aerospace industries in developing more energy efficient means of air transportation [85-89]. The hybrid gas/electric propulsion and/or the AEA concept aim at lowering or completely removing the traditional air-breathing engines, which depend on the Jet-A fuel, as a main energy source $[87,90]$. In the upcoming sub-sections, the main ideas that go beyond the conventional MEA initiative are introduced and examined. 


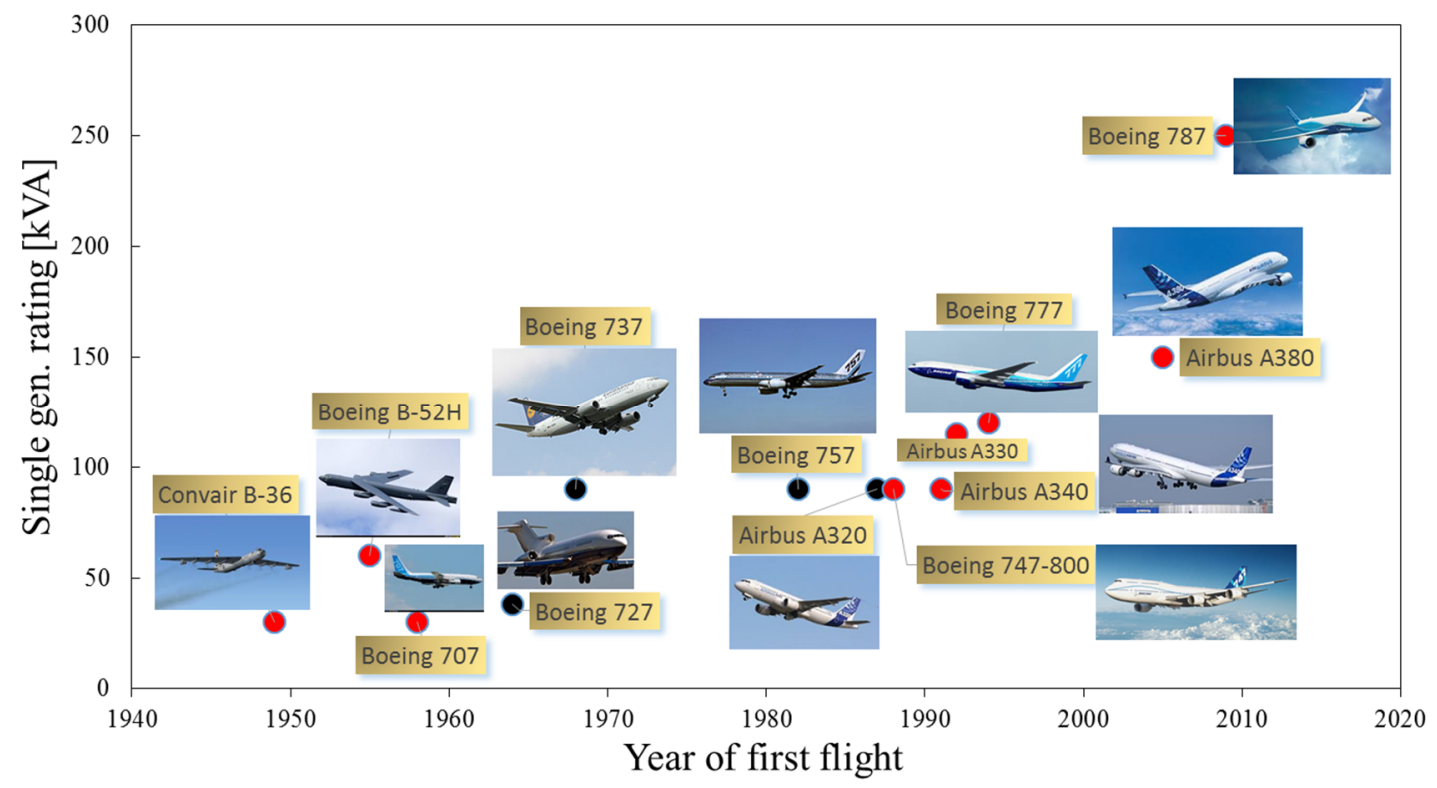

Fig. 13. Power rating of the main generators of some common aircraft (in red medium to long range aircraft, in black short to medium range aircraft).

\section{A. Multi-spool generation and HVDC systems}

Currently on modern large aircraft, turbofan engines are generally employed for propulsion. The main electrical power generator is usually driven by the HP spool (as shown in Fig. 7 and discussed in Section III), principally because the higher speed of the HP spool allows smaller size generators. Further, assuming $\mathrm{N} 1$ and $\mathrm{N} 2$ as rotational speeds of the LP and HP spools respectively, $\mathrm{N} 2$ varies in a narrower range (from idle to full power) with respect to N1 $[50,52]$. For these reasons, no generation activity was traditionally done on the LP spool (i.e. low speed). In conventional turbofan engines, the electric power extracted from the HP spool is a small fraction of the total engine power. However, the trend towards (and beyond) the MEA is resulting in an ever-growing demand for more onboard electric power; thus, any potential source of power needs to be fully utilised. Therefore, generating through multiple spools (i.e. exploiting both HP and LP spools, as prime mover for electrical generation) is fastly becoming justifiable $[34,65$, 91, 92]. The main challenge rising from using both HP and LP spools $[5,93]$ consists in the particular design attention required by the LP spool driven generator, due to the wider speed range and harsher operating conditions [67]. Indeed, N2's full-power to idle ratio $\left(N 2_{\operatorname{Max}} / N 2_{\min }\right)$ is usually around $2: 1$, whereas $N 1_{\text {Max }} / N 1_{\text {min }}$ can be more than 6:1 for high bypass ratio engines [52]. For sake of completeness, full-power to idle ratios are reported in Table $\mathrm{V}$ for some common dual spool turbofan engines, together with the "normal" operating speed of N1 and N2 [52].

With regard to the electrical machine topology, permanent magnet synchronous machines (PMSMs), induction machines (IMs) and SRMs are possible candidates for the LP spool generators $[68,94,95]$. Nevertheless, each of these machines reveals advantages and disadvantages. The principal benefits of
PMSMs are: 1) excellent power density, 2) high efficiency and 3) well-established control strategies; whilst, their drawbacks are: 1) high cost, 2) inability to operate at elevated temperatures, 3) dependent on power electronics and 4) medium reliability and fault tolerance capability. As matter of fact, the excitation field produced by the PMs is practically uncontrolled and can supply winding faults [96-98]. On the contrary, a good level of reliability and fault tolerance capability is ensured by IMs, which however do not 'enjoy' the power density levels of their PM counterparts. SRMs cannot compete with PMSMs in terms of power density and control strategy, albeit their rotor robustness makes SRMs suitable for working in harsh environments $[72,99,100]$. Finally, SRMs are also intrinsically fault tolerant, for the reasons discussed in Section IV.

TABLE V -Shaft RotationAl SPEEDS FOR COMMON DUAL SPOOL TuRbofAN ENGINES

\begin{tabular}{|c|c|c|c|c|c|}
\hline $\begin{array}{l}\text { Engine } \\
\text { Series }\end{array}$ & $\begin{array}{c}\text { Aircraft } \\
\text { (example) }\end{array}$ & $\begin{array}{l}\text { N1(100\%) } \\
\text { [rpm] }\end{array}$ & $\begin{array}{l}\text { N2(100\%) } \\
\text { [rpm] }\end{array}$ & $\frac{N 1_{\text {Max }}}{N 1_{\text {min }}}$ & $\frac{N 2_{\text {Max }}}{N 2_{\text {min }}}$ \\
\hline GP7200 & A380 & 2467 & 10998 & 6.1 & 1.9 \\
\hline CFM56 & B737 & 5175 & 14460 & 5.2 & 1.8 \\
\hline $\begin{array}{l}\text { GEnx- } \\
\text { 2B67 }\end{array}$ & B747-8 & 2560 & 11377 & 6.7 & 2.3 \\
\hline PW1100G & A320neo & NA & NA & 5.7 & 1.8 \\
\hline CF34-8C1 & $\begin{array}{c}\text { Business } \\
\text { Jet }\end{array}$ & 7400 & 17820 & NA & 1.8 \\
\hline V2500 & $\mathrm{A} 320$ & 5650 & 14950 & 4 & NA \\
\hline PW300 & $\begin{array}{l}\text { Business } \\
\text { Jet }\end{array}$ & 10608 & 26956 & NA & 1.6 \\
\hline GE90 & B777 & 2261 & 9331 & 6.1 & 1.7 \\
\hline
\end{tabular}

Aside from incrementing the generation capability, future aircraft concepts aim to improve the overall electrical power system and its architecture. In next generation aircraft, a significant weight saving could be achieved by increasing the distribution voltage $[33,101]$. As previously mentioned, 
considering the same transmitted power, a higher voltage (for the distribution system) will result in smaller cable crosssection area. Furthermore, raising the voltage will allow greater line voltage drop [101]. In fact, the minimum allowed voltage is $108 \mathrm{Vac}$, for distribution system at $115 \mathrm{Vac}$, instead $250 \mathrm{Vdc}$ are accepted on 270 Vdc systems (as per MIL-STD-704F) [100]. For these reasons, high voltage DC (HVDC) distribution systems at $270 \mathrm{Vdc}$ and $540 \mathrm{Vdc}$ are under investigation [101, 104]. Regarding the HVDC systems, the most obvious concerns are safety and the increased risk of electrical system failures, caused by the low pressure phenomenon, such as corona effects and insulation breakdown.

The migration to HVDC systems, together with the implementation of LP spool generators, will also influence the design of PECs. In this area, some of the main challenges are imputable to: a) higher operating voltage; b) elevated amount of power to be handled; and c) wider generators' operating (fundamental) frequency (for LP spool generation). Wide bandgap semiconductors, such as silicon carbide ( $\mathrm{SiC})$, are recognised, by the scientific and industrial communities, as a technology enabler [105-107].

The major features (particularly convenient for aerospace application) of SiC-based PECs, over traditional silicon-based PECs, are a) lower losses, b) better temperature tolerance, c) higher operating voltage and d) faster switching capability [105-107]. Reduced losses and high temperature tolerance help to decrease thermal management specifications [106], hence smaller and less expensive cooling systems are necessary for SiC-based PECs. Further, high operating voltage and fast switching capability lead to a potential decrement of both PECs' weight and size [107]. In particular, higher switching frequencies contribute to the reduction of filtering passive component size [107], while less series-connected modules (than traditional silicon-based counterpart) would be adopted for managing higher voltages [106].

\section{B. Future aircraft concepts}

Some of the most attractive concepts for future aircraft are represented by hybrid electric (e.g. Pipistrel Hypstair) [108, 109], distributed electric (e.g. NASA-DEP) [110], turbo electric (e.g. Rolls Royce / Airbus E-Thrust) [111] and fully electrical (e.g. Airbus E-Fan) aircraft [112]. All these configurations are characterised by an intensive electrification, since electric power is not only used for secondary systems, but also for propulsion purposes. For instance, the Airbus / Siemens / Rolls Royce "E-Fan X hybrid-electric technology demonstrator" is anticipated to fly in 2020 [85]. This program has two objectives, such as: a) replacing one of the four gas turbine engines of a traditional British Aerospace 146 (as well-known as BAe 146) with a $2 M W$ electric motor; and b) introducing a $2 M W$ generator (in the classical turbo-electric system style), powered by a Rolls-Royce AE 2100, which is used as an auxiliary power unit (APU) [85]. The success of these concepts, besides from relying on high performance electrical machines and PECs, will be strongly dependent on the technological development of energy storage systems. Modern electrochemical batteries have proven to be suitable for powering unmanned aerial vehicle and hybrid/electric light aircraft, for short endurance missions [90, $109,113,114]$. Nonetheless, for energising a fully-electric, short-haul civil aircraft, the energy density of the currently available battery technologies needs to improve by at least eight or ten-fold.

\section{Electrical systems and sub-systems in future aircraft}

As previously pointed out, high power density and reliable electrical machines and PECs will be the key enabling technologies, in future aircraft systems. Significant work across a range of aviation authorities has recently gone into defining road-maps for the technology requirements of such systems [86, 87, 115].

\section{1) High power density specifications}

For electrical systems, it is clear that today's state of the art is still not at the demanded power density levels for future aircraft, comprising all electric and hybrid electric propulsion. A quantitative analysis, whose results are compiled in Table VI, indicates the predicted electrical machine power density specifications for the short-, mid- and long-term future [86, 117]. Considering the analysis outcomes, the long-term goal is only achievable by the practical application of nonconventional technologies, such as superconductivity; whereas the short- and mid-term targets are feasible using more conventional technologies strengthened by a high level of innovation. Indeed, electrical machines with power densities higher than $10 \mathrm{kVA} / \mathrm{kg}$ have already been manufactured and tested [117], and an example is reported in the following sub-section.

TABLE VI - ELECTRICAL MACHINE POWER DENSITY SPECIFICATIONS FOR FUTURE AIRCRAFT

\begin{tabular}{|c|c|c|}
\hline $\begin{array}{l}\text { Time- } \\
\text { lines }\end{array}$ & $\begin{array}{c}\text { Predicted Power } \\
\text { Density }\end{array}$ & Enabling Technology \\
\hline By 2025 & $10 \mathrm{kVA} / \mathrm{kg}$ & $\begin{array}{l}\text { Liquid cooling, Low Loss Steel, } \\
\text { High Breakdown-Strength } \\
\text { Insulating Materials, Additive }\end{array}$ \\
\hline By 2035 & $20 \mathrm{kVA} / \mathrm{kg}$ & $\begin{array}{c}\text { Manufacturing, Nanocomposite- } \\
\text { Based Magnetic Materials [86, } \\
116,118,119]\end{array}$ \\
\hline By 2050 & $40 \mathrm{kVA} / \mathrm{kg}$ & $\begin{array}{l}\text { All the above }+ \text { Superconducting } \\
\text { materials }\end{array}$ \\
\hline
\end{tabular}

\section{2) Enabling technologies}

In order to reach such performance, a number of technology enablers are today being studied and investigated by research communities. These include new magnetic and electrical materials [118, 119], advanced modelling [120, 121] and manufacturing processes $[122,123]$, new thermal management techniques [124-126], high-speed systems [116] and better understanding of failure mechanisms [127, 128]. The latter involves advancements in power electronics (e.g. wide bandgap devices), machines (e.g. new, high strength, low losses steels) and controllers (e.g. high bandwidth control algorithms). The relationship between the technology impact of the enablers on the drive (or its components) general performance and the technology maturity is illustrated in a visually-representative manner in Fig. 14. 


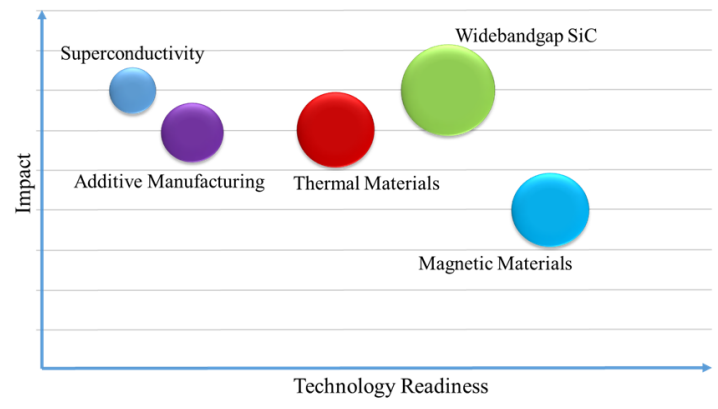

Fig. 14. Enablers: impact vs. readiness.

A power generation system for a more electric business-jet, implementing some of the aforementioned features, is the electrical machine described in [129-131], which was developed within the authors' organization. This generator is a $45 \mathrm{kVA}$ surface mount PMSM, capable of working also as engine starter (i.e. starter-generator), and it is shown in Fig. 15.

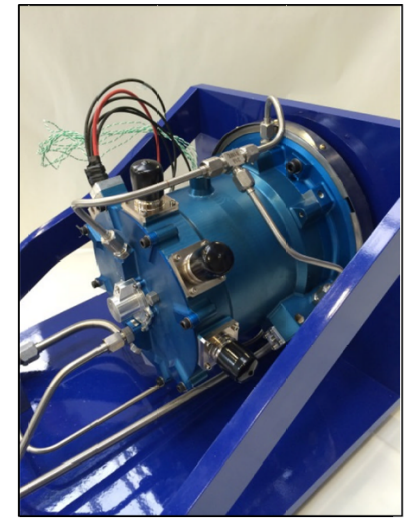

Fig. 15. A state of the art, PM generator developed at the University of Nottingham.

Some of the innovative attributes characterizing this machine are: 1) a carbon fibre PMs retention mechanism, 2) low losses, high grade, non-oriented silicon steel 3) novel thermal management involving the use of direct oil cooling of the stator core, 4) advanced high energy density PMs, 5) multi-level PEC design configuration and 6) the use of higher voltage rating materials, that allows operation at the new $540 \mathrm{~V}$ HVDC buses, being considered for future aircraft. These characteristics have contributed to achieve a power density higher than $16 \mathrm{kVA} / \mathrm{kg}$, confirming the high impact of some of the technology enablers reported in Fig. 14 and highlighting the way towards the future of the aircraft industry.

\section{CONCLUSION}

This paper provides a 'journey' along the evolution of electric power generation on-board of aircraft, by addressing the main technologies adopted over more than a hundred years time span. The advantages and disadvantages of the most common generation systems are analysed. The aircraft power requirements and the generation power trends are reported and discussed. The level of generated power was firstly affected by the transition from DC to AC generation. Then a constant growth rate is highlighted until the recent implementation of the MEA concept. In fact, the migration to AC variable frequency generation systems represented an important step towards modern aircraft. The state of the art and the major challenges of the MEA concept are also reviewed, keeping in mind the role played by electrical machines, in terms of power density and technology. Finally, some considerations related to future aircraft are drawn.

\section{REFERENCES}

[1] I. Moir, A. Seabridge, and M. Jukes, "Electrical Systems," in Civil Avionics Systems 2nd Edition, ISBN: 978-1-118-34180-3, ed: John Wiley \& Sons, 2013, pp. 235-290.

[2] J. A. Rosero, J. A. Ortega, E. Aldabas, and L. Romeral, "Moving towards a more electric aircraft," IEEE Aerospace and Electronic Systems Magazine, vol. 22, pp. 3-9, 2007.

[3] B. Sarlioglu and C. T. Morris, "More Electric Aircraft: Review, Challenges, and Opportunities for Commercial Transport Aircraft," IEEE Transactions on Transportation Electrification, vol. 1, pp. 54-64, 2015.

[4] M. Galea, C. Gerada, T. Raminosoa, and P. Wheeler, "Design of a high force density tubular permanent magnet motor," in The XIX International Conference on Electrical Machines - ICEM 2010, 2010, pp. 1-6.

[5] C. R. Avery, S. G. Burrow, and P. H. Mellor, "Electrical generation and distribution for the more electric aircraft," in Universities Power Engineering Conference, 2007. UPEC 2007. 42nd International, 2007, pp. 1007-1012.

[6] X. Roboam, "New trends and challenges of electrical networks embedded in "more electrical aircraft"," in Industrial Electronics (ISIE), 2011 IEEE International Symposium on, 2011, pp. 26-31.

[7] X. Roboam, B. Sareni, and A. De Andrade, "More electricity in the air: Toward optimized electrical networks embedded in more-electrical aircraft," IEEE industrial electronics magazine, vol. 6, pp. 6-17, 2012.

[8] M. Sinnett, "Boeing: 787 No-Bleed Systems: Saving Fuel and Enhancing Operational Efficiencies," AERO Quaterly QTR_04 07, 2007. Available: http://www.boeing.com/commercial/aeromagazine/articles/atr 4 07/AE RO_Q407.pdf Accessed: Dec. 2017.

[9] T. Nelson, "787 Systems and performance," Available: http://myhres.com/Boeing-787-Systems-and-Performance.pdf Accessed: Dec. 2017.

[10] I. O. Hockmeyer, "The generation and regulation of electric power in aircraft: a survey of design features of generators and their control," Electrical Engineers - Part II: Power Engineering, Journal of the Institution of, vol. 93, p. 2, 1946.

[11] "Aerospace Industries Association of America; The 1939 Aircraft Year Book," Washington, D.C: Aeronautical Chamber of Commerce of America.

[12] "Aerospace Industries Association of America; The 1938 Aircraft Year Book," Washington, D.C: Aeronautical Chamber of Commerce of America.

[13] W. K. Boice and L. G. Levoy, "Basic considerations in selection of electric systems for large aircraft," Electrical Engineering, vol. 63, pp. 279-287, 1944

[14] I. Moir and A. Seabridge, "Electrical Systems," in Aircraft systems: mechanical, electrical and avionics subsystems integration. ISBN: 1119965209. vol. 52, ed: John Wiley \& Sons, 2011, pp. 181-237.

[15] "Paralleled A.C. The case for constant-frequency systems," Flight and Aircraft Engineer 30 Jan. 1959 - 0337 pp. 164-166 Available: https://www.flightglobal.com/pdfarchive/1959.html Accessed: Dec. 2017.

[16] M. A. Cordner, W. A. Flygare, and D. H. Grimm, "Integrated drivegenerator system," U.S. Patent 4,252,035, 1981.

[17] J. L. Lando, "Fixed frequency electrical generation system and corresponding control procedure," U.S. Patent 7,064,455 B2, 2006.

[18] A. I. Bertinov, "Aircraft Electrical Generation," Air Force System Command, 1959.

[19] "Aerospace Industries Association of America; The 1941 Aircraft Year Book," Washington, D.C.: Aeronautical Chamber of Commerce of America.

[20] W. J. Clardy, "Electric power for airplanes," Electrical Engineering, vol. 59, pp. 385-388, 1940. 
[21] A. K. Hyder, "A Century of Aerospace Electrical Power Technology," Journal of Propulsion and Power, vol. 19, 2003.

[22] B. Adkins, W. Philipp, and A. Hossle. (1956, Electrical machines for aircraft. Proceedings of the IEE - Part A: Power Engineering 103(1S), 116-127. Available: http://digitallibrary.theiet.org/content/journals/10.1049/pi-a.1956.0017

[23] "[Online] Available: http://content.aviation-safetybureau.com/allmembers/faa-h-8083-31-amt-airframe-vol1/sections/chapter9.php Accessed: Feb. 2018."

[24] "Aerospace Industries Association of America; Aircraft year book 1953," Washington, D.C.: Aeronautical Chamber of Commerce of America.

[25] E. Sili, F. Koliatene, and J. P. Cambronne, "Pressure and temperature effects on the paschen curve," in 2011 Annual Report Conference on Electrical Insulation and Dielectric Phenomena, 2011, pp. 464-467.

[26] W. L. Berry and J. P. Dallas, "Higher-voltage D-C Aircraft Electric Systems," Transactions of the American Institute of Electrical Engineers, vol. 63, pp. 843-849, 1944.

[27] Airbus, "WRC-15 Agenda Item 1.17 - Industry's Motivation," EC - CEPT Workshop on World Radiocommunication Conference 2015, 2015.

[28] C. Sciascera, P. Giangrande, C. Brunson, et al., "Optimal design of an electro-mechanical actuator for aerospace application" in 2015 Annual Conference of the IEEE Industrial Electronics Society, Japan.

[29] "DC Starter-Generator Solutions," Thales Group, 2014.

[30] T. B. Holliday, "Applications of electric power in aircraft," Electrical Engineering, vol. 60, pp. 218-225, 1941.

[31] D. W. Exner, "Parallel Operation of Airplane Alternators," Transactions of the American Institute of Electrical Engineers, vol. 62, pp. 755-760, 1943.

[32] C. Severns, "Reflections on the preliminary electrical power system design for a large transportation airship," in 18th AIAA Lighter-Than-Air Systems Technology Conference, 2009, p. 2865.

[33] K. Emadi and M. Ehsani, "Aircraft power systems: technology, state of the art, and future trends," IEEE Aerospace and Electronic Systems Magazine, vol. 15, pp. 28-32, 2000.

[34] Y. Jia and K. Rajashekara, "Induction Machine for More Electric Aircraft: Enabling New Electrical Power System Architectures," IEEE Electrification Magazine, vol. 5, pp. 25-37, 2017.

[35] R. J. Kennett, "Integrated drive generators for aircraft," Electronics and Power, vol. 17, pp. 73-76, 1971.

[36] N. Jiao, W. Liu, J. Peng, S. Mao, and H. Zhang, "Design and control strategy of a two-phase brushless exciter for three-stage starter/generator," in 2014 IEEE Energy Conversion Congress and Exposition (ECCE), 2014, pp. 5864-5869.

[37] S. Nuzzo, M. Galea, C. Gerada and N. Brown "Analysis, Modeling, and Design Considerations for the Excitation Systems of Synchronous Generators" in IEEE Transactions on Industrial Electronics, vol. 65, issue 4, pp. 2996 - 3007, 2018.

[38] P. Wheeler and S. Bozhko, "The More Electric Aircraft: Technology and challenges," IEEE Electrification Magazine, vol. 2, pp. 6-12, 2014.

[39] B. Stephen, "Constant speed drive and generator," U.S. Patent 3576143 A, 1971.

[40] L. Setlak, "Overview of aircraft technology solutions compatible with the concept of mea," Electronical Engineering Issue 1-E (8) 2015, vol. 2015, 2015.

[41] R. M. Richard Secunde, David Repas, "Integrated Engine-Generator Concept for aircraft Electric Secondary Power," in Nasa Technical Memorandum TM X-2579, ed, 1972.

[42] S. B. Barnhardt, "Cooling arrangement for an integrated drive-generator system," U.S. Patent 4284913 A, 1981

[43] L. Andrade and C. Tenning, "Design of the Boeing 777 electric system," in Proceedings of the IEEE 1992 National Aerospace and Electronics Conference (NAECON 1992), 1992, pp. 1281-1290 vol.3.

[44] T. Glennon, "Sundstrand Corp: The 400-Hz aircraft power-generation systems: Advancing the baseline," NASA. Lewis Research Center Aircraft Elect. Secondary Power; p 1-12; (SEE 19840001988), 1983.

[45] I. Moir, "More-electric aircraft-system considerations," in IEE Colloquium on Electrical Machines and Systems for the More Electric Aircraft (Ref. No. 1999/180), 1999, pp. 10/1-10/9.

[46] J. F. Gieras, "High speed machines," in Advancements in Electrical Machines 1st edition, ISBN 978-1-4020-9007-3, ed: Springer, 2008, pp. 81-109.

[47] A. Abdel-Hafez, Power Generation and Distribution System for a More Electric Aircraft-A Review: INTECH Open Access Publisher, 2012.
[48] A. E. Reyad Mohamed Abdel-fadil, "Electrical Distribution power systems of modern civil aircrafts," 2nd International Conference on Energy Systemss and Technologies, Feb. 2013, Cairo, Egypt, 2013.

[49] "European Aviation Safety Agency ; Type-Certificate Data Sheet for GE90 Series engines," Available: https://www.easa.europa.eu/documentlibrary/type-certificates Accessed: Dec. 2017.

[50] Rolls-Royce, "Accessory drive," in The Jet Engine 5th edition. ISBN: 0 902121235 , ed Derby, England, 1996, pp. 65-71.

[51] J. R. Bart, B. A. Beutin, P. Charles, and G. Morel, "Twin spool turbine engine with power take-off means on the low-pressure and high-pressure rotors, and power take-off module for the turbine engine," Safran Aircraft Engines SAS. U.S. Grant US7552591B2, 2006.

[52] "European Aviation Safety Agency; Engines Type-Certificate Data Sheets," Available: https://www.easa.europa.eu/document-library/typecertificates Accessed: Dec. 2017.

[53] [Online] Available: https://grabcad.com/library/2-spool-high-bypassturbofan Accessed: Feb. 2018.

[54] M. J. Cronin, "Aircraft providing variable and constant electric power," U.S. Patent 4587436 A, 1986.

[55] A. Eid, H. El-Kishky, M. Abdel-Salam, and M. T. El-Mohandes, "On Power Quality of Variable-Speed Constant-Frequency Aircraft Electric Power Systems," IEEE Transactions on Power Delivery, vol. 25, pp. 55$65,2010$.

[56] A. Al-Timimy, P.Giangrande, M. Degano, et al, "Comparative study of permanent magnet-synchronous and permanent magnet-flux switching machines for high torque to inertia applications", 2017 IEEE Workshop on Electrical Machines Design, Control and Diagnosis, Pages 45-51, 2017.

[57] F. Cupertino, G. Pellegrino, P. Giangrande, et. al., "Model based design of a sensorless control scheme for permanent magnet motors using signal injection", in 2010 Energy Conversion Congress and Exposition, Atlanta, GA, USA, September 2010

[58] I. Moir and A. G. Seabridge, "Vehicle Managment Systems," in Military Avionics Systems, ed: John Wiley \& Sons, Ltd, 2006, pp. 399-401.

[59] K. Vijayakumar, R. Karthikeyan, S. Paramasivam, R. Arumugam, and K. N. Srinivas, "Switched Reluctance Motor Modeling, Design, Simulation, and Analysis: A Comprehensive Review," IEEE Transactions on Magnetics, vol. 44, pp. 4605-4617, 2008.

[60] D. A. Torrey, "Switched reluctance generators and their control," IEEE Transactions on Industrial Electronics, vol. 49, pp. 3-14, 2002.

[61] M. E. Elbuluk and M. D. Kankam, "Potential starter/generator technologies for future aerospace applications," IEEE Aerospace and Electronic Systems Magazine, vol. 12, pp. 24-31, 1997.

[62] P. Giangrande, F. Cupertino and G. Pellegrino, "Modelling of linear motor end-effects for saliency based sensorless control", in 2010 IEEE Energy Conversion Congress and Exposition, Atlanta, GA, USA, September 2010

[63] A. Al-Timimy, M. Degano, P. Giangrande, et al., "Design and optimization of a high power density machine for flooded industrial pump," in 2016 International Conference on Electrical Machines, Lausanne, 2016, pp. 1480-1.

[64] A. V. Radun, C. A. Ferreira, and E. Richter, "Two channel switched reluctance starter/generator results," in Proceedings of APEC 97 - Applied Power Electronics Conference, 1997, pp. 546-552 vol.1.

[65] A. J. Mitcham and N. Grum, "An integrated LP shaft generator for the more electric aircraft," in IEE Colloquium on All Electric Aircraft (Digest No. 1998/260), 1998, pp. 8/1-8/9.

[66] J. A. Weimer, "Electrical power technology for the more electric aircraft," in [1993 Proceedings] AIAA/IEEE Digital Avionics Systems Conference, 1993, pp. 445-450.

[67] C. Gerada, M. Galea, and A. Kladas, "Electrical machines for aerospace applications," in 2015 IEEE Workshop on Electrical Machines Design, Control and Diagnosis (WEMDCD), 2015, pp. 79-84.

[68] S.A Odhano, P.Giangrande, R.Bojoi and Gerada, "Self-commissioning of interior permanent magnet synchronous motor drives with high-frequency current injection", 5th Annual IEEE Energy Conversion Congress and Exhibition, Pages 3852-3859, 2013

[69] A. Al-Timimy, M. Degano, Z. Xu, et al. "Trade-off analysis and design of a high power density PM machine for flooded industrial pump," in 2016 Annual Conference of the IEEE Industrial Electronics Society, Florence, 2016, pp. 1749-1754.

[70] E. Richter and C. Ferreira, "Performance evaluation of a $250 \mathrm{~kW}$ switched reluctance starter generator," in Industry Applications Conference, 1995. Thirtieth IAS Annual Meeting, IAS '95., Conference Record of the 1995 IEEE, 1995, pp. 434-440 vol.1. 
[71] A. Radun, "Generating with the switched reluctance motor," in Applied Power Electronics Conference and Exposition, 1994. APEC '94. Conference Proceedings 1994., Ninth Annual, 1994, pp. 41-47 vol.1.

[72] A. G. Jack, B. C. Mecrow, and J. A. Haylock, "A comparative study of permanent magnet and switched reluctance motors for high-performance fault-tolerant applications," IEEE Transactions on Industry Applications, vol. 32, pp. 889-895, 1996.

[73] P. Wheeler, "The more electric aircraft: Why aerospace needs power electronics?," in 2009 13th European Conference on Power Electronics and Applications, 2009, pp. 1-30.

[74] R. I. Jones, "The More Electric Aircraft: the past and the future?," in IEE Colloquium on Electrical Machines and Systems for the More Electric Aircraft (Ref. No. 1999/180), 1999, pp. 1/1-1/4.

[75] J. A. Weimer, "The role of electric machines and drives in the more electric aircraft," in Electric Machines and Drives Conference, 2003. IEMDC'03. IEEE International, 2003, pp. 11-15 vol.1.

[76] V. Crespo Cavalcanti and C. Andrade, "A Trade-off Study of a Bleedless and Conventional Air Conditioning Systems," presented at the 2008 SAE Brasil Congress and Exhibition, 2008.

[77] J. Hale, "787 Design for Maintainability," ATEC, Apr. 2007. Available: http://www.vaughn.edu/assets/downloads/ATEC-2008-01.pdf Accessed: Dec. 2017.

[78] "Aircraft Commerce; Can the $787 \&$ A350 transform the economics of long-haul services?," Aircraft Commerce Issue No. 39; February/March $2005,2005$.

[79] "Reported Operating Cost and Utilization of More Than 500 Wide-body Aircraft," [Online] Available: http://www.planestats.com/bhsw 2014sep Accessed: Dec. 2017.

[80] "Aircraft Operating Costs," Aviation Week June 30, 2014; Page 6. Available: http://aviationweek.com/sitefiles/aviationweek.com/files/uploads/2014/06/avd 06 30 2014 cht1.pdf Accessed: Dec. 2017

[81] D. V. Makarov, A. S. Khlebnikov, A. V. Geist, and P. A. Bachurin, "Generation system with variable frequency and constant amplitude," in Proceedings of the 2011 3rd International Youth Conference on Energetics (IYCE), 2011, pp. 1-9.

[82] M. Hirst, A. Mcloughlin, P. J. Norman, and S. J. Galloway, "Demonstrating the more electric engine: a step towards the power optimised aircraft," IET Electric Power Applications, vol. 5, pp. 3-13, 2011.

[83] Airbus, "Airbus Global Market Forecast 2017-2036," Available: http://www.airbus.com/aircraft/market/global-market-forecast.html Accessed: Dec. 2017

[84] Boeing, "Current Market Outlook 2017-2036," Available: http://www.boeing.com/commercial/market/current-market-outlook2017/ Accessed: Dec. 2017.

[85] Airbus, "Airbus, Rolls-Royce, and Siemens team up for electric future.," [Online] Available: http://www.airbus.com/newsroom/pressreleases/en/2017/11/airbus--rolls-royce--and-siemens-team-up-forelectric-future-par.html Accessed: Dec. 2017.

[86] M. Hepperle, "Electric flight-potential and limitations," Energy Efficient Technologies and Concepts of Operation, 22-24 October 2012, Lisbon, Portugal, 2012

[87] NASA, "Visions of the Future: Hybrid Electric Aircraft Propulsion," AIAA Aircraft Electric/Hybrid-Electric Power \& Propulsion Workshop, July 28, 2016.2 Available: https://ntrs.nasa.gov/archive/nasa/casi.ntrs.nasa.gov/20170002633.pdf Accessed: Dec. 2017

[88] Y.-H. Chang and P.-C. Shao, Operating cost control strategies for airlines vol. 5: African Journal of Business Management 5.26 (2011): 10396, 2011.

[89] C.I. Hill, S. Bozhko, T. Yang, et al. "More Electric Aircraft ElectroMechanical Actuator Regenerated Power Management" in 2015 IEEE International Symposium on Industrial Electronics, pp. 337-342.

[90] R. Glassock, M. Galea, W. Williams, and T. Glesk, "Hybrid Electric Aircraft Propulsion Case Study for Skydiving Mission," Aerospace. 2017; 4(3):45, 2017.

[91] T. Feehally, "Electro-mechanical interaction in gas turbine-generator systems for more-electric aircraft," PhD, University of Manchester, 2012.

[92] A. Colin, "Turbojet having an electricity generator arranged in its fan (U.S. Grant US7952244B2)," ed: Google Patents, 2009.

[93] Y. Jia and K. Rajashekara, "An induction generator based AC/DC hybrid electric power generation system for more electric aircraft," in 2015 IEEE Industry Applications Society Annual Meeting, 2015, pp. 1-7.
[94] W. Cao, B. C. Mecrow, G. J. Atkinson, J. W. Bennett, and D. J. Atkinson, "Overview of Electric Motor Technologies Used for More Electric Aircraft (MEA)," IEEE Transactions on Industrial Electronics, vol. 59, pp. 3523-3531, 2012.

[95] G. Rizzoli, G. Serra, P. Maggiore, and A. Tenconi, "Optimized design of a multiphase induction machine for an open rotor aero-engine shaft-lineembedded starter/generator," in IECON 2013 - 39th Annual Conference of the IEEE Industrial Electronics Society, 2013, pp. 5203-5208.

[96] D. Golovanov, M. Galea, and C. Gerada, "High specific torque motor for propulsion system of aircraft," in 2016 International Conference on Electrical Systems for Aircraft, Railway, Ship Propulsion and Road Vehicles \& International Transportation Electrification Conference (ESARS-ITEC), 2016, pp. 1-6.

[97] M. Galea, T. Hamiti, and C. Gerada, "Torque density improvements for high performance machines," in 2013 International Electric Machines \& Drives Conference, 2013, pp. 1066-1073.

[98] P.Giangrande, C.I.Hill, S.V.Bozhko and C.Gerada "A novel multi-level electro-mechanical actuator virtual testing and analysis tool" in 2014 IET International Conference on Power Electronics, Machines and Drives, 2014 pp. 1-6.

[99] S. R. MacMinn and W. D. Jones, "A very high speed switched-reluctance starter-generator for aircraft engine applications," in Proceedings of the IEEE National Aerospace and Electronics Conference, 1989, pp. 17581764 vol.4.

[100] C. A. Ferreira, S. R. Jones, W. S. Heglund, and W. D. Jones, "Detailed design of a 30-kW switched reluctance starter/generator system for a gas turbine engine application," IEEE Transactions on Industry Applications, vol. 31, pp. 553-561, 1995

[101] J. Brombach, T. Schröter, A. Lücken, and D. Schulz, "Optimized cabin power supply with a +/- 270 V DC grid on a modern aircraft," in 2011 7th International Conference-Workshop Compatibility and Power Electronics (CPE), 2011, pp. 425-428.

[102] J. Brombach, A. Lücken, B. Nya, M. Johannsen, and D. Schulz, "Comparison of different electrical HVDC-architectures for aircraft application," in 2012 Electrical Systems for Aircraft, Railway and Ship Propulsion, 2012, pp. 1-6.

[103] "Department of Defence, United States of America; MIL-STD-704F Aircraft Electric Power Characteristics," 2004.

[104] L. Tarisciotti, A. Costabeber, C. Linglin, A. Walker, and M. Galea, "Evaluation of isolated DC/DC converter topologies for future HVDC aerospace microgrids," in 2017 IEEE Energy Conversion Congress and Exposition (ECCE), 2017, pp. 2238-2245.

[105] R. Raju, "Silicon carbide high voltage high frequency conversion," in NIST High Megawatt Variable Speed Drive Technology Workshop, 2014.

[106] A. Elasser and T. P. Chow, "Silicon carbide benefits and advantages for power electronics circuits and systems," Proceedings of the IEEE, vol. 90, pp. 969-986, 2002.

[107] H. Zhang and L. M. Tolbert, "Efficiency impact of silicon carbide power electronics for modern wind turbine full scale frequency converter," IEEE Transactions on Industrial Electronics, vol. 58, pp. 21-28, 2011.

[108] "Siemens, Airbus and Rolls-Royce; HYPSTAIR - System Architecture, Certifiability and Safety Aspects," Symposium E-Fliegen 2016, Stuttgart. Available: http://www.hypstair.eu/wpcontent/uploads/2013/10/E2-Fliegen-Symposium-Stuttgart_SAG.pdf Accessed: Dec. 2017

[109] R. Glassock, M. Galea, W. Williams, and T. Glesk, "Novel Hybrid Electric Aircraft Propulsion Case Studies," Aeronautics and Astronautics, MDPI Journal on, vol. vol. 4, iss. 3, article 45, 2017.

[110] M. D. Moore, "Distributed Electric Propulsion (DEP) Aircraft," briefing slides, Hampton, Va.: NASA Langley Briefing Center, 2012.

[111] Airbus, "E-Thrust: Electrical distributed propulsion system concept for lower fuel consumption, fewer emissions and less noise," Available: http://company.airbus.com/service/mediacenter/download/?unid=64ea2 c23-91b1-4787-9d1d-5b22b7d716b9 Accessed: Dec. 2017.

[112] Airbus, "E-FAN The New Way To Fly," Available: http://company.airbus.com/news-media/media item $=19 \mathrm{bf} 802 \mathrm{f}-1 \mathrm{fad}$ 4ce7-b61c-b5d6eab6b51d .html Accessed: Dec. 2017.

[113] G. Avanzini, E. L. de Angelis, and F. Giulietti, "Optimal performance and sizing of a battery-powered aircraft," Aerospace Science and Technology, vol. 59, pp. 132-144, 2016/12/01/ 2016

[114] M. Gatti, F. Giulietti, and M. Turci, "Maximum endurance for batterypowered rotary-wing aircraft," Aerospace Science and Technology, vol. 45, pp. 174-179, 2015/09/01/2015.

[115] NASA, "On-Demand Mobility: Goals, Technical Challenges, and Roadmaps," 
https://ntrs.nasa.gov/archive/nasa/casi.ntrs.nasa.gov/20160006950.pdf Accessed: Dec. 2017.

[116] R. H. Jansen, C. Bowman, A. Jankovsky, R. Dyson, and J. Felder, "Overview of NASA Electrified Aircraft Propulsion Research for Large Subsonic Transports," AIAA Propulsion and Energy 2017 Forum; 10-12 Jul. 2017; Atlanta, GA; United States. Available: https://ntrs.nasa.gov/search.jsp? R=20170006235 Accessed: Dec. 2017.

[117] "Siemens, Airbus and Rolls-Royce; Electric motor from Siemens sets new world climb record," Available: https://www.siemens.com/press/PR2016120105COEN Accessed: Dec. 2017.

[118] M. Garibaldi, C. Gerada, I. Ashcroft, R. Hague, and H. Morvan, "The impact of additive manufacturing on the development of electrical machines for MEA Applications: A feasibility study," in MEA2015 More Electric Aircraft, 2015.

[119] M. Garibaldi, I. Ashcroft, M. Simonelli, and R. Hague, "Metallurgy of high-silicon steel parts produced using Selective Laser Melting," Acta Materialia, vol. 110, pp. 207-216, 2016/05/15/ 2016.

[120] S. Nuzzo, M. Galea, C. Gerada, and N. Brown, "A Fast Method for Modeling Skew and Its Effects in Salient-Pole Synchronous Generators," IEEE Transactions on Industrial Electronics, vol. 64, pp. 7679-7688, 2017.

[121] S. Nuzzo, M. Degano, M. Galea, C. Gerada, D. Gerada, and N. Brown, "Improved Damper Cage Design for Salient-Pole Synchronous Generators," IEEE Transactions on Industrial Electronics, vol. 64, pp. 1958-1970, 2017.

[122] A. Al-Timimy, G. Vakil, M. Degano, et al., "Considerations on the Effects that Core Material Machining has on an Electrical Machine's Performance," in IEEE Transactions on Energy Conversion, vol. PP, no. 99, pp. 1-1, 2018.

[123] A. Al-Timimy, M. Alani, M. Degano, et al. "Influence of Rotor Endcaps on the Electromagnetic Performance of High Speed PM Machine" IET Electric Power Applications, 2018.

[124] M. Galea, C. Gerada, T. Raminosoa, and P. Wheeler, "A Thermal Improvement Technique for the Phase Windings of Electrical Machines," IEEE Transactions on Industry Applications, vol. 48, pp. 79-87, 2012.

[125] C. Sciascera, P. Giangrande, L. Papini, C. Gerada and M. Galea, "Analytical Thermal Model for Fast Stator Winding Temperature Prediction", in IEEE Transactions on Industrial Electronics, vol. 64, n. 8, pp. 6116-6126, March 2017.

[126] Z. Xu, A. Al-Timimy, M. Degano, et al., "Thermal management of a permanent magnet motor for a directly coupled pump," in 2016 International Conference on Electrical Machines, Lausanne, 2016, pp. 2738-2744.

[127] D. Barater, F. Immovilli, A. Soldati, G. Buticchi, G. Franceschini, C. Gerada, et al., "Multistress Characterization of Fault Mechanisms in Aerospace Electric Actuators," IEEE Transactions on Industry Applications, vol. 53, pp. 1106-1115, 2017.

[128] C. Sciascera, M. Galea, P. Giangrande, et al., "Lifetime consumption and degradation analysis of the winding insulation of electrical machines" in 2016 IET International Conference on Power Electronics Machines and Drives, Glasgow; United Kingdom; April 2016.

[129] S. Bozhko, S. S. Yeoh, F. Gao, and C. Hill, "Aircraft starter-generator system based on permanent-magnet machine fed by active front-end rectifier," in IECON 2014 - 40th Annual Conference of the IEEE Industrial Electronics Society, 2014, pp. 2958-2964.

[130] M. Degano, P. Arumugam, W. Fernando, T. Yang, H. Zhang, J. B. Bartolo, et al., "An optimized bi-directional, wide speed range electric starter-generator for aerospace application," in 7th IET International Conference on Power Electronics, Machines and Drives (PEMD 2014), 2014, pp. 1-6.

[131] Z. Xu, A. L. Rocca, S. J. Pickering, C. Eastwick, C. Gerada, and S. Bozhko, "Mechanical and thermal design of an aeroengine starter/generator," in 2015 IEEE International Electric Machines \& Drives Conference (IEMDC), 2015, pp. 1607-1613.

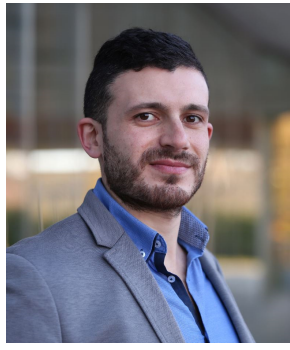

Vincenzo Madonna (S'17) received the BSc degree in Electronic Engineering from University of Calabria, Italy, in 2012 and the MSc degree in Electrical Engineering from the University of Bologna, Italy, in 2016. In 2012 he was an Exchange Student at KU Leuven, Belgium, and in 2015 he was a Visiting Researcher at the University of Nottingham, UK. He is currently a Marie Curie Researcher and $\mathrm{PhD}$ candidate in electrical machine design within the Institute for Aerospace Technology (IAT) and the PEMC group at the University of Nottingham, UK. His research interests include design, thermal management and lifetime prediction modelling of electrical machines. Mr. Madonna received the qualification of Italian Chartered Engineer in 2016.

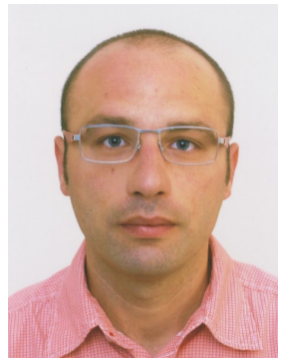

Paolo Giangrande received the Bachelor's (Hons.) and Master's (Hons.) degrees in electrical engineering at the Politecnico of Bari in 2005 and 2008, respectively. During 2008, he was a Marie Curie Intra-European Fellow at the University of Malta. He received his $\mathrm{PhD}$ in electrical engineering at the Politecnico of Bari in 2011. Since January 2012, he is Research Fellow at the University of Nottingham (UK), within the Power Electronics, Machines and Control Group. From 2017, he is the head of the Accelerated Lifetime Testing Laboratory at the Institute of Aerospace Technology, Nottingham. His main research interests include sensorless control of AC electric drives, design and testing of electromechanical actuators for aerospace, thermal management of high-performance electric drives and reliability and lifetime modelling of electrical machines.

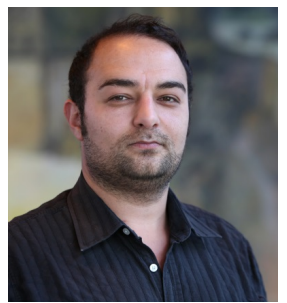

Michael Galea (M'13) received his $\mathrm{PhD}$ in electrical machines design from the University of Nottingham, UK, where he has also worked as a Research Fellow. He is currently the Head of School of Aerospace in the University of Nottingham, Ningbo, China, where he is also the Director of Aerospace. He currently lectures in Electrical Drives and in Aerospace Systems Integration and manages a number of diverse projects and programmes related to the more / all electric aircraft, electrified propulsion and associated fields. His main research interests are design, analysis and thermal management of electrical machines and drives, the more electric aircraft and electrified and hybrid propulsion. 